\title{
Kolonoskopi sonrası nadir bir komplikasyon: Akut apandisit
}

\author{
A rare post-colonoscopy complication: Acute appendicitis
}

\section{(D) Muhammed Fatih AYDIN ${ }^{1}$, (D) Sabiye AKBULUT², (D) Hüseyin AKYOL ${ }^{3}$, (D) Mehmet Akif AYDIN ${ }^{3}$}

Istanbul Altınbaş Universitesi, Medical Park Bahçelievler Hastanesi, ${ }^{1}$ Gastroenteroloji Bilim Dall, Istanbul

Sağllk Bilimleri Üniversitesi, Kartal Koşuyolu Yüksek Ihtisas Sağllk Uygulama ve Araştırma Merkezi, ${ }^{2}$ Gastroenteroloji Bilim Dahl, Istanbul

Özel Medical Park Bahçelievler Hastanesi, ${ }^{3}$ Genel Cerrahi Bölümü, Istanbul

Gaitada gizli kan pozitifliği saptanan 50 yaşında, erkek hastaya tarama amaçlı kolonoskopi yapıldl. Kolonoskopide çekuma kadar gidildi; çekum tabanı, apendiks orifisi, ilioçekal valv normal olarak izlendi. Total kolonoskopisi tamamlanan hasta, gözlem sonrası herhangi bir komplikasyon gelişmemesi üzerine, ișlemden yaklașık bir saat sonra taburcu edildi. Kolonoskopi işleminden 24 saat sonra karın ağrısı yakınması ile tekrar başvurdu; tüm abdominal bilgisayarlı tomografi çekildi ve akut apandisit tanısı konularak, laparoskopik apendektomi yapild. Patolojik inceleme sonucu akut flegmenöz apandisit olarak rapor edildi. Kolonoskopi sonrası akut apandisit oldukça nadir, fakat önemli bir komplikasyondur. Biz kolonoskopi işlemi sonrası akut apandisit gelișen bu olguyu oldukça nadir görülmesi nedeniyle sunmaktayız.

Anahtar kelimeler: Kolonoskopi, akut apandisit, akut karın ağrısı, komplikasyon

\section{GİRİs}

Kolonoskopi gastrointestinal sistem hastalıklarının tanı, tedavi ve tarama programlarında çok yaygın olarak kullanılan, oldukça emniyetli, endoskopik bir işlemdir. Sık olmamakla birlikte iyi bilinen komplikasyonları kanama, perforasyon, divertikülit ve postpolipektomi sendromudur (1). Kolonoskopi sonrası akut apandisit oldukça nadir fakat önemli bir komplikasyondur (2). Biz burada kolonoskopi işlemi sonrası gelişen bir akut apandisit olgusunu oldukça nadir görülmesi nedeniyle sunmaktayı.

\section{OLGU SUNUMU}

Elli yaşındaki gaitada gizli kan pozitifliği saptanan erkek hastaya tarama amaçlı kolonoskopi planlandı. Gerekli ön hazırlıklardan sonra, hastadan yazılı ve sözlü onam alınarak, hastaya kolonoskopi işlemi yapıldı. Kolonoskopide çekuma kadar gidildi; çekum tabanı, apendiks orifisi (Resim 1), ilioçekal valv, çıkan kolon, hepatik fleksura, transvers kolon, splenik fleksurada mukoza ve lümen normaldi. Inen kolonda, yaklaşık 2-3 mm çaplarında, üç adet diminutif polip izlendi, hepsi biyopsi forsepsi ile çıkarıldı. Sigmoid kolon ve rektum mukoza ve lümen normaldi. İşlemden yaklaşık bir saat sonra hasta taburcu edildi.

Aydın MF, Akbulut S, Akyol H et al. A rare post-colonoscopy complication: Acute appendicitis. Endoscopy Gastrointestinal 2020;28:119-120.
Colonoscopy was performed for screening purposes in a 50-year-old male patient with positive occult blood in the stool. Colonoscopy reached the cecum; the cecum base, appendix orifice, and iliocecal valve were normal. The patient, whose total colonoscopy was completed, was discharged approximately $1 \mathrm{~h}$ after the procedure, as no complications developed after observation. At $24 \mathrm{~h}$ after the colonoscopy procedure, he presented again with abdominal pain. Complete abdominal computed tomography was performed, and a diagnosis of acute appendicitis was made. Laparoscopic appendectomy was then performed. Pathological examination revealed acute phlegmenous appendicitis. Acute appendicitis after colonoscopy is an extremely rare but critical complication. The rare case presented herein developed acute appendicitis after colonoscopy.

Key words: Colonoscopy, acute appendicitis, acute abdominal pain, complication

Hasta, kolonoskopi işleminden 24 saat sonra sağ alt kadranda lokalize karın ağrısı yakınması ile tekrar başvurdu. Fizik muayenesinde batın sağ alt kadran palpasyonda hassas idi,

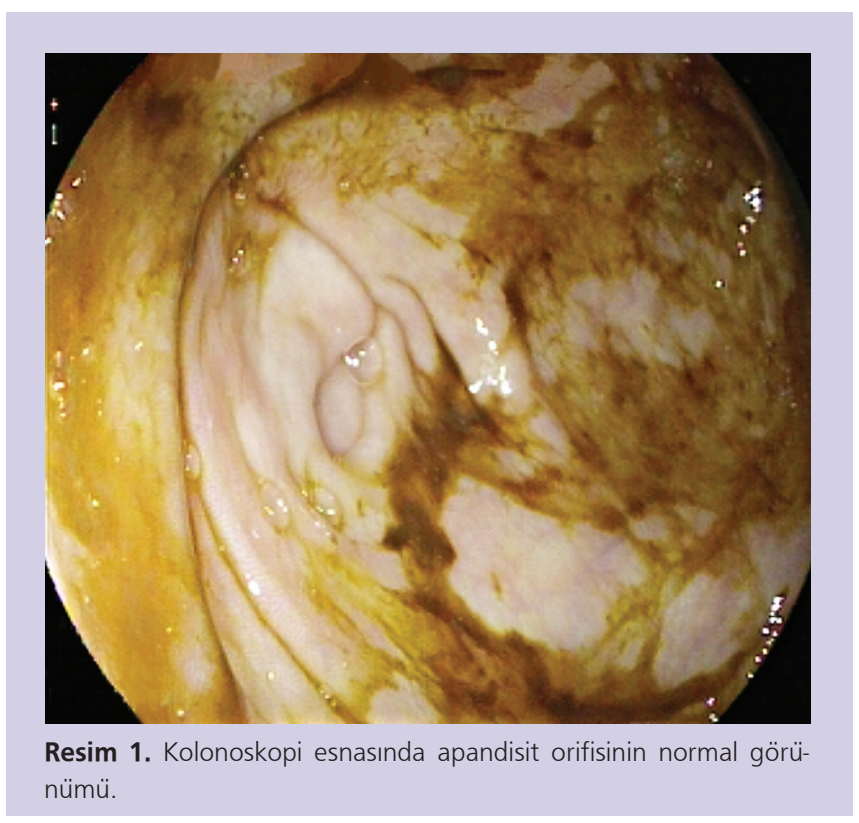

İletişim: Sabiye AKBULUT Sağlık Bilimleri Üniversitesi İstanbul Kartal Koşuyolu Yüksek İhtisas Sağlık Uygulama ve Araştırma Merkezi İstanbul, Türkiye• sabiye4@hotmail.com Geliş Tarihi: 12.10.2020 Kabul Tarihi: 14.10.2020

Bu olgu; 1-6 Aralı 2017 tarihinde Antalya'da yapılan 34. Ulusal Gastroenteroloji Haftası'nda poster olarak sunulmuştur. 


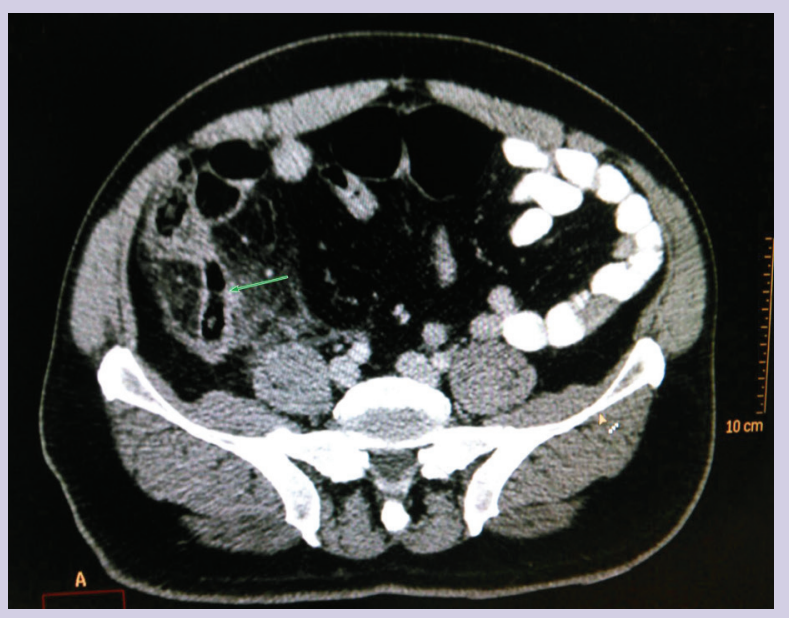

Resim 2. Abdominal BT'de akut apandisitin görünümü (yeşil ok)

defans vardı ve rebound pozitifti. Beyaz küre $12.800 / \mathrm{mm} 3$, nötrofil oranı \%80.1, C-reaktif protein (CRP) $68 \mathrm{mg} / \mathrm{dl}(\mathrm{N}$ : 0-0.5 mg/dl) idi. Abdominal bilgisayarlı tomografi (BT) çekildi. BT'de akut apandisit ile uyumlu görünüm izlendi (Resim 2); apendiks çapı $15 \mathrm{~mm}$, içi hava sıvı ile distandü idi, periapendiküler yağ dokusunda inflamasyon, ödem ve dansite artışı mevcuttu, batında serbest hava izlenmedi. Hastaya laparoskopik olarak apendektomi yapıldı. Operasyon materyalinin patolojik incelenmesi sonucu 'akut flegmenöz apandisit' olarak rapor edildi. Genel durumu iyi olan hasta şifa ile taburcu edildi. Hastadan bilgilendirilmiş onam alındı.

\section{TARTIŞMA}

Kolonoskopi özellikle kolon kanseri taramasında, 50 yaş üzerinde ve/veya gaitada gizli kan pozitif bulunan kişilerde çok yaygın olarak kullanılan, altın standart değerinde, oldukça emniyetli ve düşük riskli bir işlemdir (1). Kolonoskopi işlemi sonrası karın ağrısı, bulantı, kusma, barsak spazmı ve kolonun mukozal çiziği çok görülebilen, minör komplikasyonlardır. Kolonoskopi sonrası hayatı tehdit eden ve nadir görülen komplikasyonlar; ince barsak perforasyonu, volvulus,

\section{KAYNAKLAR}

1. April MD, Simmons JR, Nielson AS. An unusual cause of postcolonoscopy abdominal pain. Am J Emerg Med 2013;31:273.el-4.

2. Yagnik VD, Yagnik BD. Post-colonoscopy appendicitis: a rare entity. Clin Pract 2012;2:e55.

3. Chae HS, Jeon SY, Nam WS, et al. Acute appendicitis caused by colonoscopy. Korean J Intern Med 2007;22:308-11

4. Paramythiotis D, Kofina K, Papadopoulos V, Michalopoulos A. Diagnostic colonoscopy leading to perforated appendicitis: A case report and systematic literature review. Case Rep Gastrointest Med 2016;2016:1378046. obstrüksiyon, strangülasyon, mezenterik iskemi, kolesistit, pankreatit, apandisittir (2).

Postkolonoskopik apandisit oldukça nadir, fakat önemli bir komplikasyondur ve insidansı literatürde \%0.038 olarak belirtilmektedir (3). Yayınlarda apandisit semptomlarının kolonoskopi işleminden 6. saat ila 5. gün arasında başladığı bildirilmektedir. Yapılan bir çalışmada bizim olgumuzda da olduğu gibi akut apandisit vakalarının çoğunluğunun (\%68.42) kolonoskopi işleminden 24 saat sonra geliştiği rapor edilmiştir (4).

Bizim olgumuzda kolonoskopi esnasında apendiksin görünümü normal idi. Postkolonoskopik apandisitin oluşum mekanizması tam olarak bilinmemekle beraber, durumu açılayacak çeşitli teoriler bulunmaktadır. Bunlar cihazın apendikse direk travması, apendiksin intübasyonu, fazla verilen hava ile apendiksin aşırı gerilmesi, cihazla apendiks orifisine girilmesi veya fekal tıkacın apendiks lümenine itilmesi ile lümenin t1kanması veya apendiks orifisi etrafında bulunan bir lezyona girişim yapılması sayılabilir $(5,6)$. Kolonoskopi işlemi sonrası gelişen karın ağrısı nedenleri; genellikle gaz retansiyonu, spazm ve postpolipektomi sendromuna bağlıdır. Karın ağrısının uzun sürmesi, sağ alt kadranda odaklanması, palpasyonda defans ve rebound bulgularının pozitif olması akut apandisiti akla getirmelidir. Böyle durumlarda, abdominal BT preoperatif dönemde kullanılan seçkin bir yöntemdir (7).

Postkolonoskopik apandisitin tedavisi cerrahidir. Apendektomi açık veya laparoskopik yöntemle yapılır; fakat barsak perforasyonu veya intraabdominal sepsis gibi olası komplikasyonlar düşünülüyorsa eksploratris laparotomi tercih edilmelidir (6).

Sonuçta, postkolonoskopik apandisit kolonoskopinin çok nadir, fakat önemli ve gözden kaçabilen bir komplikasyonudur. Kolonoskopi sonrası karın ağrısı ile gelen hastalarda ayırıcı tanıda akut apandisit akla gelmelidir. Zamanında tanı konulması ve hastanın zamanında cerrahiye refere edilmesi oldukça önemlidir.

\section{Tüm yazarlar herhangi bir çıkar çatışması olmadığını be- yan ve kabul ederler.}

5. Johnston P, Maa J. Perforated appendicitis after colonoscopy. JSLS 2008; 12:335-7.

6. Kafadar MT, Bilgiç I, Kartal S, Güliter S. An unusual cause of acute abdomen: Post-colonoscopy appendicitis. Turk J Surg 2018;34:340-1.

7. Jambhekar A, Robinson S, Lindborg R, Rucinski J, Borriello R. A different type of perforation: appendicitis after colonoscopy. JRSM Open 2018;9:2054270418815108. 